\title{
Страхиња ПОЛИТ
}

ДАНОЈЛИЋЕВИ

Учитељски факултет, ПОЕТИЧКИ СВЛАКОВИ

Београд

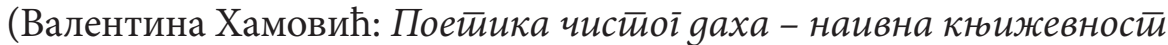
Милована Данојлића, Београд: Службени гласник, 2018, 279 стр.)

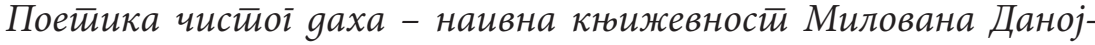
лића Валентине Хамовић представља својеврсни наставак ширег истраживачког подухвата. Ауторка у овој монографији остаје на трагу испитивања модернистичких тенденција у српској књижевности за децу након објављене студије Два йесника ӣреврайника (2008) о упоредној анализи поетика Васка Попе и Душана Радовића. У обе студије настоји да испита и опише сва поетичка преиначења модерне поезије за децу, с јасном свешћу о њеним неотуђивим везама с књижевним променама у српској књижевности уопште. Студија о Данојлићевом наивном стиваралашйву још једном потврђује тај научно-истраживачки импулс и додатно шири опсеге својих запажања о овим темама.

Поетичка чистиоі gaxa Валентине Хамовић има циљ да из различитих перспектива осветли Данојлићево наивно стваралаштво. У врло прегледно структурисаној монографији, читалац опажа намеру ауторке да феномен наивної ситуира у контекст Данојлићеве поетике у целости, тражећи поетичке ослонце у експлицитно поетичким и књижевно-критичким освртима самог аутора, али и у ширем књижевноисторијском контексту. Пратећи ауторкине аналитичке увиде, уочава се намера за узглобљавањем Данојлићеве наивне књижевности (али и књижевности за децу уопште) у шири књижевни систем, легитимизујући њен статус и неодвојивост од онога што се назива, у аналогији с њом, књижевношћу за одрасле. Ова секундарна интенција истраживача чини се подједнако важном, нудећи читаоцу, на примеру једне сложене поетике која се не може замислити без наивноі успостављеног доживљаја света, још један прилог апологији књижевности за децу као аутономног и равноправног књижевноуметничког израза.

Са свешћу о Данојлићевом поетичком динамизму, Валентина Хамовић своју студију започиње општим прегледом његовог стваралаштва. Књижевне мене Милована Данојлића, описане у одељку 
„Ка поетици врхунске једноставности“, јасно показују разлоге и тренутке у којима је његово поетичко меандрирање отворило простор наивној йесми. Генеза Данојлићеве поезије омогућава ауторки да прецизно и убедљиво аргументује моменат формирања свести о наивној поезији, а потом и низа песничких збирки које из ње произлазе. Функционалност овог уводног поглавља је вишеструка, будући да показује и моменат зачећа идеје о наивној песми и, што је једнако важно, даје увид у јединствену, амбивалентностима и дивергирањима склону, поетичку самосвест Милована Данојлића.

Прво од три поглавља Поейике чистиої gaxa („Концепт наивне песме“) представља систематизацију Данојлићевих ставова о поезији за децу. Ауторка прати процес формирања концепта наивне песме и преиспитује фундаментална обележја песникових ставова о књижевности за децу. Будући да је Милован Данојлић према њој превасходно изградио поетичко обзорје, а тек потом се ослањајући на њега упустио у стварање поезије за децу, Валентина Хамовић у првој целини студије нуди врло разгранато и детаљно осветљавање особености које творе њено поетичко упориште. Пратећи кључне ставове Данојлићеве есејистике о концепту наивне песме, Валентина Хамовић указује на њихову двоструку важност - они су уједно и кључ за разумевање Данојлићеве наивне (али, како то ауторка убедљиво показује, и целокупне) поетике, и важан моменат за апологију целокупне књижевности за децу у српској култури. Прецизније речено, унутар ове целине преиспитује се Данојлићева теоријска концепција наивне песме: од терминолошке постулације, схватања наивног у поезији, укидања дистинкције између поезије за децу и поезије за одрасле, до испитивања исходишта песничког редукционизма који доводи до поезије „врхунске једноставности“. Ауторка сходно томе трага за замецима Данојлићеве поетике наивног, изналазећи их у авангардно схваћеном комуникационом коду, окренутом прапочецима и изворима, ослобођеном од талога културе, као и у књижевно-критичким идејама Гастона Башлара, Бенедета Крочеа и Фридриха Шилера. Исто тако, важно је истаћи да се Данојлићева књижевнотеоријска гледишта не перципирају као самоникле појаве већ се посматрају у сложеном сплету културолошких и књижевних промена с краја педесетих и почетка шездесетих година прошлог века.

Друга целина студије („Наивна песма и прича“) посвећена је испитивању поетичких особености Данојлићевог песничког и приповедачког опуса који почива на концепту наивної. Из тог разлога, у поглављима се посвећује пажња и оним текстовима који нису превасходно окренути млађем реципијенту већ припадају тзв. іраничној књижевности, окренутој и деци и одраслима. Чини се да је у томе и највећи допринос ове студије - ауторка на трагу прецизно постулираних ставова о Данојлићевом концепту наивности маркира 
тачку пресека у његовој поетици, према којој се даље могу осветлити све његове поетичке манифестације, било да је реч о поезији или прози, „за децу“ или „за одрасле“.

Целина о Данојлићевој наивној поезији хронолошки прати поетичку еволуцију из збирке у збирку, од књиге песама Како сйавају ирамваји до Велике йијаце из 2006. године. Са свешћу о претходним критичким судовима о њима, ауторка нуди низ нових запажања и накнадних увида у Данојлићеве поетичке свлакове. Данојлићева поезија за децу посматра се и као својеврстан песнички манифест, фигуријајући у целокупном опусу као песничка легитимизација наивне поезије, али и својеврсни (само)обрачун с модерном поезијом. Блискост збирке Како сйавају тирамваји с песничким изразом из Урођеничких йсалама показују јасна поетичка превирања и потребу за ревидирањем лирског израза, довевши је на пола пута између „онога што је у њој gечије и онога што је у њој за gеиу“ (107). Таква колебања приметна су на тематско-мотивском и стилском плану, као и у позицији лирског гласа, што и показују ауторкине компаративне анализе песничких збирки за децу и одрасле. Анализа збирки Фуруница јоїуница и Роgна іоoина потврђују Данојлићеву склоност поетичким меандирањима. Прва збирка открива увођење топоса завичаја, у смеру од напуштања простора града ка окретању сеоском амбијенту и природи. За Валентину Хамовић песма „Ограда на крају Београда“ представља симболичку тачку и „упоришни меланхолични мит о изгубљеном или недосегнутом завичају“ (109) - што потврђују и касније анализирани прозни текстови: Змијин свлак, Сенке око куће, Гоgина иролази кроз авлију и други. Збирке Роgна їоgина, Фуруница јоїуница и Песме за веома йамейну gеиу перципирају се као нова стваралачка прекретница која доноси чулно конкретне и натуралистички засноване песме из којих провирује и метафизичка димензија песама (Роgна іоguна), или као „моменат надилажења дотадашње песничке праксе“ (134) и окретање игри, иронији, депатетизацији и демитологизацији социјалних и историјских тема. Последња песничка збирка Велика йијаца још једном показује Данојлићеву измењену песничку парадигму, отварајући простор за доминантно епско начело, најисторичнијег и социјално најсамосвеснијег тематско-мотивског регистра. Такође, једнака пажња посвећена је и архитектоници поменутих збирки, песниковим каснијим интервенцијама и измењеним односом према циклизацији појединих песама, чиме се изнова потврђује Данојлићева поетичка несмиреност и разноличје.

Валентина Хамовић показује да је једини интерпретативни пут којим се може ићи кроз Данојлићево стваралаштво напоредно сагледавање свих његових књижевних манифестација. Будући да Данојлићевом делу приступа као органској целини у којој се откривају различита прожимања и амбиваленције, њене анализе прозних тек- 
стова ослањају се на тумачење поезије и обрнуто. Конституисање опуса лирских романа сматра се „складиштем читавог низа разнородних литерарних и ванлитерарних поступака“ (173), па се као окоснице у тумачењу узимају мотиви завичајности, детињства, пантеистички доживљај природе и различити уметнички поступци, попут детаљних описа дневних феномена, смене годишњих доба, склоности минијатури и инсистирање на лирским пејзажима. Наведени елементи видљиви су, како студија и потврђује, у свим жанровским варијацијама Милована Данојлића. Пратећи пут Данојлићеве „наивне приче“, Валентина Хамовић илуструје како се дати мотиви обликују на фону начела о наивној песми, мимо жанровских задатости, у „одсуству канона и позе“ (183). Поводом Змијиної свлака закључује да се је реч о „наивној“ визији света у којој се могу опазити и наноси „сентименталног“ слоја који надилази сензибилитет наивне свести. Реч је о роману који тематизује путовање у прошлост, ка завичају; иако немогућ у целости, повратак омогућује својеврсни пут ка самоспознаји. Највећи простор посвећен је ипак роману Гоguна йролази кроз авлију. Перципиран као најцеловитија еманација концепта наивног стваралаштва у Данојлићевом прозном опусу, овај роман је, према ауторки, и својерсна дискурзивна реализација свих идеја уобличених у претходним збиркама дечје поезије. Песничке слике из ранијих збирки у овом роману добијају своје прозне аналогоне. Динамизам романа почива на удвојености наративне позиције, доживљајног и приповедног ја, кроз чију се медијаторску позицију у први план смештају простор и време „као истински јунаци романа“ (206). Колико је тешко жанровски одредити Данојлићеву прозу најбоље показује ауторкино колебање у прецизирању његовог одређења - он се, према ауторки, може посматрати као „роман-хроника“ и „роман простора“, а тиме се можда потврђује немогућност традиционалне теорије жанрова да модернистички обликоване текстове (какав је и овај) опише. Управо је хронотоп, уз удвојену наративну перспективу, послужио Валентини Хамовић да у својој студији успостави тематску и поетичку везу међу овим романима. Од хронотопа авлије из романа Гоgина йролази кроз авлију, преко Сенке око куће, па до Мести а рођена и других романа, ауторка успоставља темељне тематско-мотивске координате Данојлићеве прозе (и поезије). Простор куће перципира се као својеврсни нуклеус, увек у релацији с опозитном сликом града и градске средине, из ког се шире даље теме: породични односи, проблематизовање фигуре оца, одрастање, понекад чак (ауто)иронично интонирано.

Последња целина монографије („Слика детињства у поезији и прози Милована Данојлића“) својеврсна је сума претходних запажања. Кроз теме детињства речи, детињства поезије, детињства света и феномен самог детињства конституише се „базични арсенал песничких слика“ и један „виши облик незнања“. Данојлић 
артикулише јединствен књижевни израз, који супротставља „нарушеној духовној равнотежи" савременог друштва и појединца у њему.

Поетиика чистио општу поетичку многоликост Данојлићеве наивне књижевности: с једне стране групише и систематизује пређашње књижевно-научне судове о њој, а с друге нуди и низ нових и књижевнонаучне пажње вредних запажања, што је уједно и њен највећи допринос. Говорити о протејским поетикама, у какве несумњиво спада и Данојлићева, није лако, али, како Поейика чистиої gaxa показује - и те како је могуће. 